\title{
Preliminary Report on Diseases of Tomato in Choba, Rivers State.
}

\author{
WOKOMA, E. C. W. \\ Dept of Microbiology, University of Port Harcourt. P. M. B. 5323, Port Harcourt, Nigeria.
}

\begin{abstract}
Diseases of tomato were investigated in four plots at a University farm located in Choba, a community of the Niger Delta Region of Nigeria. Disease symptoms included irregular leafspots, dark brown lesions with chlorotic halos, vein clearing, chlorosis, yellowing, blight, wilts and defoliation. Flower blight and drop was observed in the plants that reached the flowering stage before dieing. Other symptoms were stunting, stem canker, die-back, shriveling of stem and death. Fusarium oxysporum f. sp. lycopersici, Verticillium albo-atrum and Rhizoctonia solani were the three fungi isolated on acidified potato dextrose agar from symptomatic roots and stems of permanently wilted plant samples. Pathogenicity of isolates was established. There is evidence to suggest that Fusarium, Verticillium and Rhizoctonia spp. limit production of tomato in this part of Nigeria. The study also confirms earlier reports that Fusarium wilt limits tomato production in the forest zone and also establishes Verticillium wilt and Rhizoctonia stem canker and root rot as other important diseases limiting tomato production in Rivers State. Therefore the production of tomato requires the development of efficient control systems to reduce economic loss associated with these diseases. @ JASEM
\end{abstract}

Tomato (Lycopersicum esculentum Mill.) is grown in many parts of Nigeria both as wet and dry season crops. Although most tomato production is at a small scale in backyard gardens, there are a few commercial fields. In Northern Nigeria where dry season tomato is grown under furrow irrigation, foliar diseases are less. Consequently, tomato crops grown in Northern Nigeria have higher yields and better quality fruits. Wilts caused by Fusarium oxysporum f. sp. lycopersici Snyd.\& Hans., Sclerotium rolfsii Sacc. and Pseudomonas solanacearum E.F. Smith are the important diseases of tomato in the Savanna and forest zones of Nigeria (Erinle 1986). Among the wilt diseases, Fusarium wilt is most prevalent, particularly among the local varieties, which are very susceptible. Wilts of tomato are also prevalent and damaging to tomato in other countries (El-Abyad et al. 1993, El-Shanshoury et al. 1996, Quasem 1996, Sharma and Norwak 1998, De Cal et al. 1999).

In Rivers State, tomato is produced on a small scale with the local varieties being planted as intercrop with okra, cocoyam, pepper, garden egg, etc. This is unlike Kaduna, Benue, Plateau, and other states in Northern Nigeria where they are grown commercially. The cost of a standard 50 kilogram basket of tomato from Benue and Plateau states sold in Port Harcourt, Rivers State ranged between for $\$ 4000$ to $\$ 12000$ depending on the time of purchase within the year. A personal communication with some local farmers revealed that many farmers were not growing tomato on a large scale because of diseases which hindered fruiting. Many attributed the diseases to unfavourable soil conditions which could not be explained. Symptoms reported by farmers included wilting, yellowing and death of plants before or after flowering. The investigations reported in this paper were initiated to determine causes of diseases and premature death of tomato in parts of the Niger Delta region of Nigeria.

\section{MATERIALS AND METHODS}

\section{Experimental plot design}

The study area was located in Choba in Obio-Akpor Local Government of Rivers State. The location has arable marshy vegetation, well-drained, highly acidic fluvisol. The total annual rainfall is about $2400 \mathrm{~mm}$ and temperature ranges from $25^{\circ} \mathrm{C}$ to $38^{\circ} \mathrm{C}$ in the dry season. The field studies were conducted between December and April (dry season). Four farmlands were selected for the field investigation. After clearing, four plots were demarcated and labeled with wooden pegs. Each plot was 12 by 6 metres. Tomato seeds were extruded from ripe tomato fruits purchased at the Fruit Garden Market, Port Harcourt. Seeds were surfaced sterilized in $1 \%$ sodium hypochlorite for $5 \mathrm{~min}$, then rinsed in three changes of water and air-dried overnight before planting. Planting was in December. Prior to planting the plots were watered to soften the dry soil. Planting depth was $2-3 \mathrm{~cm}$, plant spacing $50 \mathrm{~cm}$, and row spacing $100 \mathrm{~cm}$. Each seeded area was marked with 4 sticks pegged opposite each other and watering was carried out twice daily, in the morning before $7 \mathrm{a} . \mathrm{m}$. and in the evening after 6 p.m. Ten days after planting, seedlings trimmed to one seedling per hole.

\section{Evaluation of disease progress}

Plants were observed on alternate days for onset of disease symptoms, which appeared about 10 weeks after emergence. The heights of the plants at the $10^{\text {th }}$ week ranged from 30 to $44 \mathrm{~cm}$. Beginning at the onset of symptoms, plants in each plot were visually examined for wirestem, crown rot and dieback while the leaves were examined for foliar symptoms such 
as chlorosis, vein clearing, leafspots, yellowing, wilting and defoliation. When wilting was apparent, plants were watered, marked with wooden pegs and observed for an additional three days to determine if the wilting was temporary or permanent. Permanently wilted plants were carefully uprooted, placed in labeled polyethylene bags and at $6 \pm 2{ }^{\circ} \mathrm{C}$, until isolations were carried out on the samples. Five wilted plants were uprooted from each plot. Field observations continued for four months after planting.

\section{Isolation of suspect pathogens}

Necrotic stems and roots were washed in running tap water after removing the adhering soil particles and sectioned into 1-1.5 cm pieces. Sectioned tissues were surface sterilized in $1 \%$ sodium hypochlorite solution for five min, rinsed in three changes of sterile distilled water. Five segments from each plant was aseptically plated on acidified potato dextrose agar (APDA) acidified with $1 \mathrm{ml}$ per litre of lactic acid then incubated at $29 \pm 2^{\circ} \mathrm{C}$, in the dark for 3-5 days. Following incubation six $\mathrm{mm}$ disk of fungal growth from each section was transferred to petri dishes containing freshly prepared APDA and incubated as previously stated, to obtain pure cultures. In cases of mixed cultures, each culturally distinct growth was sectioned and transferred to APDA plates to obtain pure cultures.

\section{Identification of isolates and maintenance of cultures}

Each culturally distinct isolate purified on APDA for five days was picked with a flame-sterilized dissecting needle, and examined at x200 magnification in a drop of lactophenol cotton-blue stain under a microscope (Leitz, England). Isolates were identified using standard text (Barnett and Hunter 1972).

Some isolates obtained from diseased root segments grew slowly after purifying on APDA. To induce rapid growth, tomato dextrose agar (TDA) was used for subsequent culturing and maintenance of pure culture of the isolated fungi. The TDA medium was prepared as follows. Two hundred $g$ of washed ripe tomato fruit was ground with $200 \mathrm{ml}$ distilled water in a blender (Moulinex, England) then passed through two layers of cheesecloth. To the filtrate was added $20 \mathrm{~g}$ bactoagar (Oxoid), $20 \mathrm{~g}$ dextrose (Oxoid) and the volume made up to $1 \mathrm{~L}$ with distilled water. The medium was heated to dissolve the agar, then autoclaved at $121^{\circ} \mathrm{C}, 1.03 \mathrm{~cm}^{2}$ for $15 \mathrm{~min}$. Approximately $15 \mathrm{ml}$ of cooled molten medium was dispensed into $9 \mathrm{~cm}$ disposable petri plates. After cooling, plates were seeded in the centre with $6 \mathrm{~mm}$ disk of each isolate purified on APDA plates and incubated for 4 days at ambient temperature $\left(29 \pm 2^{\circ}\right.$ C), in the dark.

\section{Pathogenicity tests}

Healthy two-week-old seedlings were grown outdoors in $8.5 \mathrm{~cm}$ diameter plastic pots containing sterilized sandy-loam soil. The soil was sterilized by autoclaving at $121^{\circ} \mathrm{C}, 1.03 \mathrm{~kg} \mathrm{~cm}^{-2}$ for $1 \mathrm{~h}$, for three consecutive days. Three surface sterilized seeds were planted in each pot and watered daily, until plants were two-week-old. Four pots of similar size, filled with sterilized moistened sandy-loam soil were inoculated with five mycelia disks of $6 \mathrm{~mm}$ diameter, cut from the edged of actively growing culture of each culturally and morphologically distinct fungus. The disks were incorporated into the soil with a garden trowel and each pot was watered once daily for two days to enable the fungus colonize the soil. For the control, five sterile $6 \mathrm{~mm}$ TDA plugs were incorporated into the sterile soil in four pots. Three two-week-old seedlings were carefully uprooted, wounded at the crown area with a sterile dissecting needle and transplanted into each pot containing moistened soil incorporated with either fungal disks or sterile disks. All experimental plots were maintained outdoors between March and April. The outdoor temperature fluctuated between $34^{\circ}$ and $38^{\circ}$ C. Pots were watered daily and symptom development monitored for two weeks.

\section{RESULTS \\ Symptoms in field plots}

The symptoms observed in the field plots in each farmland, which were similar and typical of tomato wilt diseases are described below.

Plot 1 Chlorosis of leaves starting from the lower leaves progressing upward, with black irregular leaf spots, browning, drying and defoliation near the base of stems of diseased plants was also observed. These symptoms were accompanied by falling over, wilts and eventual death of the plant. All the plants in the plot exhibited these symptoms but disease progression varied from one plant to another.

Plot 2 Chlorosis, browning and drying of leaves started from the leaf apex and margins of the lower leaves. Large dark brown spots with chlorotic halos were found on some leaves. Disease symptoms on leaves appeared as slight vein clearing on the outer young leaflets of infected plants followed by drooping of the petioles of older leaves. Plants were stunted $(34 \mathrm{~cm})$. Wilting was initially temporary but was later followed by permanent wilting. Wilting of plants in this plot was rapid and severe all the plants exhibited the same symptoms.

Plot 3 Yellowing of leaves at the base of the stem, brown leaf spots, blighting and defoliation of leaves starting from the base of the stem and progressing 
upwards. The plants finally showed dieback and wilt symptoms.

Plot 4 Yellowing and drying of leaves from the leaf apex with dark brown leaf spots. Temporary wilt was followed by permanent wilt. Stem and leaves dried up completely.

\section{Isolation and identification of the suspect pathogens}

Fungal growth occurred on all symptomatic tissue cut from the twenty plants plated on APDA (Table 1). Some of the isolates grew rapidly having black mycelia growth on one half of the culture and brown growth on the other half. Initially two fungal species were suspected; therefore both brown and black segments were sub cultured on different APDA plates. Microscopic examinations of both cultures revealed that both fungi had similar characteristics, except that the black, pigmented culture produced sclerotia after 10 to 12 days while the brown, pigmented culture did not produced sclerotia. The isolate had septate hyphae, with long cells and was characterized by right-angled branching. Both cultures were identified as Rhizoctonia solani Kuhn. To identify the isolates as $R$. solani, they were characterized as having multinucleate cells branching near the distal septum of cells with constriction of the branch near the point of origin (Anguiz and Martin 1989). The black culture produced sclerotia of varying sizes and numbers, which were distributed on the surface of the colony. This fungus was isolated from plots 1 and 3 .

Table 1. Distribution of root-infecting wilt pathogens on tomato in field plots in Choba, Rivers State.

\begin{tabular}{llll}
\hline Plot/ & \multicolumn{3}{l}{ Frequency of root infecting with pathogens $(\%)^{\mathrm{a}}$} \\
\cline { 2 - 4 } farmland & E. oxysporium & V. albo-atrum & $R$. solani \\
1 & 100 & 0 & 40 \\
2 & 40 & 60 & 0 \\
3 & 0 & 0 & 100 \\
4 & 100 & 0 & 0 \\
\hline
\end{tabular}

Some fungal isolates produced extensive cottony pink mycelium in culture, the pink pigment being more pronounced on the underside of the culture. Growth on APDA was slow when compared with growth of the other isolates, but was enhanced on TDA. Under the microscope, variable conidiophores and two kinds of conidia were apparent. The large macroconidia were hyaline, several celled (5 to 6 cells), boat shaped with slightly pointed ends. The microconidia were one celled, ovoid, numerous, borne singly and also hyaline. Some intermediate 2 to 3 celled hyaline conidia were also seen under the microscope. The fungus was identified as Fusarium oxysporum f. sp. lycopersici Synd. \& Hans. The fungus was isolated from plots 1, 2 and 4 (Table 1).
The third group of fungal isolates produced white extensive mycelium with small clusters of conidia in culture. Slender, branched, verticillate conidiophores were apparent in the wet mounts. Conidia were hyaline, ovoid and one celled. The fungus was identified as Verticillium albo-atrum Reinke \& Berth. This fungus was isolated from diseased tomato plants uprooted from plot 2 only. Of the three fungi, $F$. oxysporum f. sp lycopersici was more frequently isolated from the symptomatic tissues. Both Fusarium and Rhizoctonia solani were isolated from some of the diseased tissues. The incidence of $V$. albo-atrum among the uprooted plants was low. The fungus was isolated from three of the twenty diseased plants uprooted from the field and these plants were uprooted from plot 2 . In contrast, $F$. oxysporum $\mathrm{f}$. $\mathrm{sp}$ lycopersici was isolated from most of the diseased plant samples. Rhizoctonia solani was isolated from the five diseased plants uprooted from plot 3.

\section{Pathogenicity tests}

All the three fungi induced wilt symptoms on the tomato seedlings planted in the fungus-infested soils. Symptoms development varied but plants grown in Verticillium-infested soil showed the most severe blight and wilt. Plants grown in the Fusariuminfested soil followed this. Symptoms on plants infected with $F$. oxysporum f. sp lycopersici were chlorosis of the leaf apex and mild wilt. Plants grown in Rhizoctonia infected plots did not show signs of wilt throughout the two weeks observation period but developed water soaking and sunken legions on the stem at the soil line. As the infection progressed, the plants developed wirestem. Severely affected plants fell over. None of the plants died within the two weeks of observation, which was probably too short for death to be eminent. The inoculated plants showed disease symptoms that were similar to the symptoms observed in the field. All the seedlings planted in the control pots remained healthy throughout the experimentation period. Re-isolation of all the fungi from diseased potted plants on APDA and TDA was successful. The fungi were isolated from the roots and crown regions of the potted plants showing wilt and dieback symptoms. No fungus was isolated from plants grown in control pots where sterile TDA disks were incorporated into the soil.

Table 1 shows the distribution of root-infecting wilt pathogens in the four farmlands in Choba, Rivers State. $F$. oxysporum f. sp lycopersici was more prevalent; occurring in three farmlands $R$. solani was encountered in two farmlands and was also the only root-infecting fungus of tomato plants in one of the farmlands (plot 3). V. albo-atrum was isolated from diseased tomato plants in only one farmland (plot 2). 


\section{DISCUSSION}

Tomato is susceptible to many diseases that reduce its yield, the most sewers of which are vascular wilts caused by $F$. oxysporum $f$. sp lycopersici, $V$. alboatrum and Pseudomonas solanacearum, and early blight caused by Alternaria solani (Erinle 1986, ElAbyad et al. 1993, El-Shanshoury et al. 1996). Erinle (1986) reported that wilt of tomato in the savanna zone of northern Nigeria was caused by $F$. oxysporum f. sp. lycopersici, Sclerotium rolfsii and $P$. solanacearum, with Fusarium wilt being the most prevalent with disease in the field. The most common symptoms observed in Northern Nigeria are yellowing and wilting of lower leaves. These symptoms were observed in all the four plots where tomato was planted. None of the tomato plants in plots 1,2 and 4 bore fruits throughout the four months study period. Wilting was most rapid in plot 2 where $F$. oxysporum lycopersici and $V$. albo-atrum were isolated. The most prevalent wilt pathogen of field grown tomato in Choba farmlands was $F$. oxysporum f. sp lycopersici. Two wilt pathogens, $F$. oxysporum $\mathrm{f}$ sp lycopersici and $R$.. solani induced disease complex in $40 \%$ of the tomato plants in plot 1.

Diseases constitute a serious limiting factor to tomato production in Nigeria. The production of tomato in Rivers State has been hampered by diseases whose etiology was unknown to the farmers. Pathogenicity of these isolates has not been fully studied in Rivers State. However, the present study adds information to earlier reports about the role of these fungi in causing diseases of tomato (Erinle 1986). The ability of the isolates to cause wilts and stem cankers of tomato seedlings demonstrates that the major diseases limiting tomato production in Rivers State are Fusarium wilt, Verticillium wilt, and stem canker and die back incited by Rhizoctonia solani.

Other diseases observed in the field were leaf spots which may be caused by Alternaria solani and other pathogens. However, since leaf samples were not carried to the laboratory for isolation, it is possible that several fungi and bacteria may be responsible for the observed leaf spots in the field. Leaves spots of tomato plants in Nigeria have been associated with Sclerotium rolfsii, Alternaria solani, Septoria lycopersici, Xanthosomonas vesicatoria and Pseudomonas syringae (P. tomato) (Erinle, 1986). Irregular leaf spots on plants in plot 1 could be associated with several fungi. Bacterial pathogens may be the suspected causative agents of the vein clearing and large dark brown lesions with chlorotic halos found on leaves in plot 2. Other diseases of tomato are caused by viruses and nematodes. But in northern Nigeria, tomatoes grown during the cool and dry season have much less disease compared with wet season crop. Rivers state is a wet state.
Consequently, most of the tomato grown in this region will be exposed to heavy, rainfall that would promote growth of fungi by supporting rapid germination of fungal propagules that occur in the soil. Although this study resulted in the identification of some pathogens of tomato, efforts should continue to identify the causes of tomato diseases at other locations in Rivers state.

Conclusion: Several disease symptoms were evident in field grown tomato in Choba, Nigeria. Foliar symptoms included irregular leaf spots, large dark brown lesions with chlorotic halos and vein clearing. Blighting, wilting and defoliation were followed by death of severely diseased plants. Fusarium oxysporum f. sp lycopersici, $V$. albo-atrum, and $R$. solani were isolated from diseased rootss and stems. Isolates were pathogenic on two-week-old seedlings in potted trials. The present findings support earlier report that $F$. oxysporum $\mathrm{f}$. sp lycopersici is an important pathogen causing wilt disease of tomato in the savanna and forest zones of Nigeria and establishes stem canker and root rot by $R$. solani and Verticillium wilt as other important diseases limiting tomato production in Rivers State.

Acknowledgement: I thank Miss Virginia T. Brown for her technical assistance.

\section{REFERENCES}

Anguiz, R.; Martins, C. 1989. Anastomosis groups, pathogenicity and other characteristics of Rhizoctonia solani isolated from potatoes in Peru. Plant Disease 73:199-201.

Barnet, H.L.; Hunter, B.B. 1972. Illustrated Genera of Imperfect Fungi. $3^{\text {rd }}$ Edition. Burgess Publishing Company Minneapolis, Minnesota. $241 \mathrm{pp}$.

De Cal, A., Garcia-Lepe, R., Pascual, S.; Melgarejo, P. 1999. Effect of timing and method of application of Penicillium oxalicum on efficacy and duration of control of Fusarium wilt of tomato. Plant Pathology 48:260-266.

El-Abyad, M.S. El-Sayed, M.A. El-Shanshoury, and El-Sabbagh, S.M.1993. Towards the biological control of fungal and bacterial diseases of tomato using antagonistic Streptomyces spp. Plant and Soil 149:185-195.

El-Shanshoury, A.R. Abu El-Sououd, S.M., Awadella, O.A. and El-Bandy, N.B. 1996. Effect of Streptomyces corchorusii, Strptomyces mutabilis, Pendimethalin and Metricuzin on the 
control of bacterial and Fusarium wilt of tomato. Can.J.Bot. 74:1016-1022.

Erinle, I.D. 1986). Tomato Diseases in the Northern states of Nigeria. Extension Bulletin 11, Agricultural Extension and Research Liaison Services, Ahmadu Bello University, Zaria.

Quasem, J.R. 1996. Fungicidal activity of Ranunculus asiaticus and other weeds against
Fusarium oxysporium f. sp lycopersici. Ann. Appl. Biol. 128:533-540.

Sharma, V.K. and Nowak, J. 1998. Enhancement of verticillium wilt resistance in tomato transplants by in vitro co-culture of seedlings with a plant growth promoting rhizobacterium (Pseudomonas sp. Strain PSJN). Can.J. Microbiol. 44:528-536.

* Corresponding author: Wokoma, E. C. W. 